was accounted one of the leaders of that time in that cause. However, she was not as radical as many of the leaders, and although she lectured for woman suffrage she finally abandoned it for the time being, thinking it at that time impractical and inexpedient. Her later reading and study was largely along the lines of general literature.

It is said that she and her husband were very devoted to each other and that she was very helpful to him in all his great business enterprises. ${ }^{3}$

\title{
JOHN L. McCREERY AND HIS NOTED POEM
}

We are in receipt of a letter from Mrs. Albine Galpin Brown of Delhi, the old county seat of Delaware County, in which she encloses the manuscript of an article on John L. McCreery written by her daughter, Kathryn Galpin Brown, whose death occurred some two years ago. John L. McCreery was an honored citizen of Delhi in the late fifties and early sixties. Besides being superintendent of schools of Delaware County, he was also editor of the Delazare County Journal. He was also a poet of talent, and among his productions was the beautiful poem, the opening stanza being

There is no death! the stars go down

To rise upon some other shore,

And bright in heaven's jeweled crown

They shine forever more.

Its authorship was mistakenly attributed by many to the noted Lord Lytton. In 1893 when Charles Aldrich was editor of the Annals he wrote to Mr. McCreery, who then lived in Washington, D. C., and received from him a letter setting out in detail the circumstances of his writing the poem, and the confusion in the minds of the public for some years at least, of the authorship. The letter was published in the Annals, Vol. I, No. 3, October, 1893.

Miss Brown made considerable research concerning $\mathrm{Mr}$. McCreery for the prepartaion of the paper referred to above. Concerning his death and the marking of the location of his home in Delhi by the Delhi Woman's Club we are permitted to quote as follows :

\footnotetext{
2The first woman admitted to practice before the Supreme Court of Iowa was Mary B. Hickey of Newton (later Mrs. Mary Wilkinson of Pomona, California), who was admitted June 25, 1873. Mrs. Savery was admitted June 29, 1875 , and on the same day Mrs. Mary Emily Haddock of Iowa City was also admitted.

3See Des Moines Register, April 15, 1891, p. 6; April 18, 1801, p. 6.
} 
Mr. MeCreery's death followed an operation September 8, 1906, and he was laid to rest in Washington, D. C. Mrs. McCreery died early in 1925. One daughter, Mrs. Lulu Sperry of Pittsburg, Pennsylvania, survives them. The quaint old one-story house in which the McCreery family lived while in Delhi, and the spot where the famous poem was written, stood unoccupied for many years. Thus the elements aided by vandal hands, had their way with it and it fell into ruin, almost completely disappearing during the last few years. In tardy recognition of a fellowtownsman who had achieved something of note, the community became somewhat stirred at the demolition of the old landmarls, but nothing was done until the Delhi Woman's Club took up the matter. After much discussion, the lot was bought by them in January, 1920. Funds from the club treasury, augmented by contributions from old residents and friends of the McCreery family, made the purchase possible. It becarne necessary for the club to incorporate in order to hold and administer property, so on May 29, 1922, the Delhi Woman's Club became a corporation to which the lot was deeded, and plans went forward for a simple memorial. The site is a corner near the western extremity of Delhi, where the road swings in a double turn to the west and north-the road Mr. McCreery traversed on the night the inspiration for the verses came to him.

On November 1, 1924, the huge granite boulder that had finally been chosen was brought to the spot and placed on the cement base which had been prepared for it in the corner of the old foundation wall of the house. The bronze tablet which completes the memorial measures eighteen by twenty-four inches and bears, besides Mr. McCreery's name and the date of his birth and death, the first stanza of the famous poem.

The sturdy simplicity and dignity of the native rock perfectly typify the life and character of the man it honors; and through the comparatively few stanzas by which he became known, he will live on; one of the immortals, who "before us passed the Door of Darkness through"; not dead, for as he declares with such buoyant confidence, "all the boundless Universe is $\mathrm{L}$ ife:-there are no dead!"

After preparing the copy for the above we discovered there appeared in the Des Moines iribune-Capital of July 27, 1928, on page 8 , in Priscilla Wayne's department, a copy of seven of the ten stanzas identical with those of the first edition of the poem, "There Is No Death," and "E. Bulwer Lytton" is given as the author. What an example of the statement that an error put aflout can never be overtaken and entirely corrected! It is almost a humiliation that we do not claim what is due in credit and fame for our own Iowa people, but insist on giving the honor to others.

There is in the library of the Historical Department a copy of Songs of Toil and Triumph, by J. L. McCreery, which contains the poem as revised and republished by the author. In his letter to Mr. Aldrich, mentioned previously in this article, Mr. McCreery sets out at length his reasons for the revision. 
The poem does not appear in any of the works of Lytton and the library authorities give the author of the poem as $J$. L. McCreery and say "sometimes wrongfully attributed to Bulwer Lytton."

\section{FIELD NOTES OF IOWA LAND SURVEYS AND THE RADIO}

As a repository of valuable facts upon the actual establishment of permanent settlement in Iowa, we find the original notes of the surveyors who marked out our township and section lines of incomparable interest. It is not disputing or underrating the testimony of early residents upon the facts of first things in a locality, to go to the notes of those who established the permanent landmarks of that locality and there read what was recorded in confirmation or controversion of reminiscence.

It has been useful, then, to this department to refer to these notes when it is desired to know the exact location of earliest habitations, travelways and like evidences of the use of the land for our civilization.

The passing of the years since the establishment of our section corners has put out of life the direct recollection of probably every person who as a deputy surveyor certified his notes, and while we have encountered many names well known to us not only as such deputies, but as chainmen, axmen, mound-makers and other assistants who were required on a surveyor's staff and were required to autograph with him his reports, we have not been able thus far to learn within five years of one person living whose autograph was attached to these valuable data.

So it is fair to assume that the field notes of our land surveys are reliable in so far as they carry references to the evidences of both Indian and white life, Indian and white travelways, and the occurrence of fuel, building materials, soil quality, drainage and water supply that, under instructions of the surveyor general, the deputy surveyors were required to note.

A few curious variations from standard terms are employed that inspire a student to learn their cause. A surveyor in Audubon County noted on one line running north ten miles from his starting point a road, a trail and an Indian trail. In the usage of surveyors of adjacent townships the words slough, slue, and swale occur, while draw and ravine are employed to locate an 
Copyright of Annals of Iowa is the property of State of Iowa, by \& through the State Historical Society of Iowa and its content may not be copied or emailed to multiple sites or posted to a listserv without the copyright holder's express written permission. However, users may print, download, or email articles for individual use. 